\title{
Negotiating Public Sphere Modernity and Civil Society in Pesantren
}

\author{
Saifudin Asrori \\ Faculty of Social dan Political Sciences \\ UIN Syarif Hidayatullah \\ Jakarta, Indonesia \\ saifudin.asrori@uinjkt.ac.id
}

\begin{abstract}
- the contribution of pesantren in socio-economic development has been widely acknowledged. However, this Islamic educational is often considered as an institution that promotes intolerant and militant education which then becomes the root of radical movements and terrorism in Indonesia. The accusations and stereotypes of education in pesantren should be examined in the context of social change due to current the influences of modernization and globalization. The act of terror which involves a pesantren can be considered as a form of negotiation on the condition of the public sphere opposed to what is aspired. In this condition, the flow of modernization reduces the role of religion in the public sphere into private affairs, usually in the form of marginalization and the decline of the role of religion. So if modernization is understood as the marginalization of religion, the teaching and the education in pesantren can be classified as anti-modern. This article tries to answer the ability of pesantren in preparing the students to be able to participate in the era of modern society and strengthening of civil society. The role of pesantren in the era of modernization is evaluated through educational programs related ethnic tolerance, democracy and political and social justice. Based on ethnographic studies in Gontor, this article illustrates that pesantren has taken a progressive political role and played an active role in strengthening the emergence of civil society in Indonesia.
\end{abstract}

Keywords - public sphere; modernity; civil society; gontor; Indonesia

\section{INTRODUCTION}

The contribution of pesantren in socio-economic development has been acknowledged. However, this Islamic educational is often associated with the institution that promotes intolerant and militant education which later became the root of radical movement and terrorism in Indonesia. British Broadcasting Corporation (BBC) for example, when commenting on the Bali bombing, said: "one of the answers lies in Islamic colleges or pesantren, that taught and educated the strict doctrine of Islamic"[1]. Moreover, the National Agency for Combating Terrorists (or in Indonesia known as BNPT) also indicated nineteen pesantren supported the radicalism and terrorism movement [2]. The agency also recommends giving a certification for ulama or kyai. The radical act of terror involving pesantren reflects how a public sphere negotiates the idea that opposes the aspiration of the majority. The current modernization and globalization which reduces the role of religion in the public sector into private affairs, usually in the form of marginalization and the decline of the role of religion. So, if modernization is understood as the marginalization of religion, then teaching and education in pesantren can be classified as anti-modern. Another implication is that pesantren model of education is not able to accommodate changes in science and technology or provide reinforcement of plurality and democratization in the public sphere.

On the contrary, Indonesia's pesantren has made a significant contribution to the Islamic education and in turn the formation of the socio-political identity of Muslims [3]. In this educational institution, the process of Islamic learning takes place, where Muslims are introduced to the teachings of Islam so that it becomes part of their life practice. At the beginning of the 20th century, the early days of the growth of consciousness as a nation, pesantren served as the basis for the formation and dissemination of traditional Islamic ideas [4]. And, this Islamic educational institution also became one of the important bases of the formation of the santri in the 1950s. A similar role can be seen in Indonesia's development from the 1970s to the 1980s when the modernization process by the New Order government has had a powerful effect on Muslim life. The rise of a Muslim group called "the new middle class of santri"--which explored the cultural Islamist movement, replacing political Islam by old santri in the 1950s--goes hand in hand with the modernization that takes place within traditional Islamic boarding schools in Indonesia [5].

Following Cassanova, this article assumes that not all religious expressions are contrary to the strengthening of civil society and can be a destruction of the democratic structures [6]. Moreover, there are still many possibilities of religious values that are compatible with public life. Lukens-Bull's (2005) study entitled Peaceful Jihad discusses the process of modernity within the body of Indonesian Muslims, especially in East Java, which makes their 'Islamic' unique. Lukens-Bull focuses on the internal dynamics of pesantren about how Islamic teachers and leaders within the pesantren combine politics and culture into the pesantren curricula [7]. The process is an attempt to go beyond the reformist versus traditionalist approach in Islam which dubs "Peaceful Jihad" as a pesantren initiative in rejecting Jemaah Islamiyah (JI) or Laskar Jihad movements with the Sufi cultural tradition. This article focuses on the efforts of Pondok Modern (PM) Gontor 
in preparing its santri to play their role in modern society and able to support the strengthening of civil society in Indonesia.

\section{GONTOR TRANSFORMATION TOWARD THE MODERNITY}

\section{Education Based on Totalisation of Ways and Objectives}

Gontor hinges on two life values namely essential values and instrumental values. These two values are presented on five principles (panca jiwa) such as sincerity, simplicity, self-reliance, Islamic brotherhood, freedom. It also reflected by their motto that is, to build the character of the students to be a Muslim with a noble character, healthy body, broad knowledge and independent mind.

The founders formulates the instrumental values of the institution based the abstraction of variety of concept, thought and the motto of the institution. The spectrum of these values is translated into the philosophy of the institution, philosophy of education, institution's orientation, and its synthesis.

The philosophies that institution holds are: Gontor stands above, and for all groups; Gontor is a field of battle, not a place to make a profit; and This pondok is a waaf for the muslim ummah and is not the property of Kyai anymore. The philosophies of education are: to become an intellectual ulama and not an intellectual who knows about religion; live is once, so live meaningfully; and ready to be led and ready to lead. There are many other values that the institutions hold onto besides the few mentioned above [8].

Vission and mission became the cornerstone of the foundation of education based on the totality of ways and objectives. As a totality of ways means the creation of educational milieu that supports the achievement of educational ideals. Gontor is designed as an institution where teachers and students learn together in a milieu that is fully designed for education. In doing so, all activities involving the 'agreement' from all stakeholders; from student, student development department, teachers, students' families, partners of pesantren, and the headmaster Kyai's families. As totality of objectives means that all activities are directed to enhance the intelligence of student in all dimensions, be it the spiritual intelligence, intellectual intelligence, and emotional intelligence [9]. The entire processes became a unity, all in one system so that it creates a thorough success.

On cultivating of those processes, Gontor relies on the heritage and traditions of the noble boarding schools that are integrated with the systems and methods of modern education [10]. In that sense, the ideals, spirit, and philosophy of life are following a dormitory system. In Gontor, the meaning of a dormitory at boarding school system comprises schools (formal), family (informal) and community (nonformal). The school combined these three elements by involving the caregivers, teachers, and students themselves [11].

On dealing with the changing reality, Gontor holds on the slogan, "al-muhâfazhatu ala al-qadîm al-shālih wa al- akhdzu bi al-jadîd al-ashlah” (maintaining a good old tradition and taking innovations better), which is translated as a protection and projection strategy. The protection strategy is an intention to maintain the noble qualities possessed by the students by protecting them from negative environmental influences. This noble quality, in the world of pesantren, by itself includes the qualities of faith (spiritual intelligence), the quality of science (intellectual intelligence), and the quality of practices (emotional intelligence). Meanwhile, the projection strategy includes planning and developing all potentials of the santri through two approaches: individual and institutional approaches. At the individual level, this strategy refers to the development of various interests and talents of the individual in its various dimensions of intelligence, whether spiritual, intellectual, or emotional. At the institutional level, this strategy refers to strengthening and developing the institutional capacity of pesantren to achieve its educational goals, while maintaining its vision and mission, orientation, and the philosophy and motto of education and teaching [12].

\section{LIFE AND STUDY AT GONTOR}

One feature that Gontor offers is the integrated sixyear program, known as Kulliyatul Mu'allimin Islamiyah (KMI) or the Islamic Teacher Education Programme. It is equivalent to a combination of a junior and high school level of education. Its curriculum has two components: formal education conducted during the school hours and extracurricular activities under the supervision of the student development department (pengasuhan santri). Students need to pass both components in order to graduate from the school. Running the programs, Gontor formed several organizational structures to maintain the quality of its education and teaching. The high body is Waqf Board, whose duty is to elect the Grand Headmaster Kyai of Gontor and give the mandate to be responsible for running the day to day activities. Five tasks to be carried out by the Grand Headmaster are 1) running education and instruction, 2) providing infrastructures and education facilities, 3) developing waqf property and raising fund, 4) preparing re-generation, and 5) maintaining the welfare of teachers. The Kyai assisted by student development department and Kulliyyatul Mu'allimin al-Islamiyyah (KMI) department [14].

Kulliyyatul Mu'allimin al-Islamiyyah (KMI) is the department that responsible for the continuity of education and teaching. This department is coordinated by a director who has seven subordinate sections which handle of the process of teaching and learning as follows; Teacher's Career and Coaching, Research and Curriculum Development, Infrastructure, Library, Laboratory, and Administrative Section.

Gontor has the regular and intensive programmes. The regular program is for the Primary School/Madrasah Ibtida'iyah graduates with a period of 6 years of study, which is taken sequentially from Grade 1 to 6 . Meanwhile, the intensive program at KMI is for the junior high school/Madrasah Tsanawiyah and above; students have to 
study for four years, by following the sequence of Grade 1-35-6. This intensive class is specifically held for Grade 1 and 3. While in the 5th grade, santri will have to follow the regular program.

The student development department (pengasuhan santri) covers all extracurricular activities. In carrying out all the daily duties, this department assisted by several staffs. The department aims to harness and develop the students' character, which is a central focus of Gontor. This department is responsible for coordinating all student activities on 24 hours bases, which includes provides guiding and counseling for the students. The department also supervises the activities and disciplines of the santri. In upholding the discipline of students, the department is emphasizing the preventive awareness and minimalization of giving the punishment. The strategies of Gontor in strengthening santri's discipline are as follows; 1) the exemplary system is a strategy of the exemplary attitude of the kyai, teachers, caregivers, and students; 2) the creation of a conducive environment which means creating a situate where everyone is able to see, hear, feel, work in, and experience the lements of education; 3) the briefing system meaning that activities should begin with a briefing, especially on the values of education contained therein; 4) the habitualization system is a strategy to running educational programs from the light to the heavy one with a high discipline, so using coercion is somestimes permitted; 5) the assignment system that is a strategy of involvement in the organizations of educational activities [15].

\section{DISCUSSION}

In the context of Gontor, modern values such as ethnic tolerance, democracy, political and social justice have become the bases of the education. it is taught formally by the teacher in the classroom, and informally in the daily life of the students. The civic education material is formulated to teach democracy and ethnic tolerance. During students' activities school also teach democracy and tolerance through the arrangement of their dormitories. Gontor's regulations stipulate that each year students are required to transfer the dorm. Every semester students will also experience a shift in the dormitory they live in. In a sense, all students must undergo a systematic shift to another housing in order to foster the diversity of their social life. The aim is to give the variety to students and to guide them to them expand relationships and opened their minds to the various traditions and cultures. In this process, the student will learn about tolerance without being forced and they will to do it by directly practicing it.

Gontor gives the student ample opportunities to develop their leadership skills and mental skills. One of the strategies is by involving all students in the informal and nonformal educations. The students are given the responsibility to manage their own activities under the umbrella of Student Organizations. The Student Organization, or known as Organisasi Pelajar Pondok Modern (OPPM) is running under the supervision of the senior teachers. The chairman of each student organization is elected by the students through the process of syûrâ, where students origin city-based group chose one representative. Subsequently, the chosen representatives deliberate among themselves to elect five candidates for chairman, two of which will be decided by the headmaster (kiai) as the chairman and its deputy [16].

Besides the student organization, there are dormitories organizations, the scout movement organizations, sports club, public speaking club, English and Arabic club and city-based club. Students have the option to choose activities according to their talent and preference. This implies that those who are not involved in one student organizations still have opportunities in the other organizations. This strategy promotes students' responsibilities, leadership, cooperation skill and also very beneficial in enhancing the development of the students' emotional quotient and spiritual quotient through activities outside the classroom. Hence, all students have to participate in this activity. The organizations are selfgoverned, which means the students themselves do the planning, organizing, and implementing the activities, while the schools' staff will only do supervision [14].

\section{CONCLUSION}

Islamic based educational institutions, particularly Gontor, is an institution that empowers modern values of education. Gontor does not only give religious education but also provide an extra education in building the character and developing the capacity of a person based on the character of kinship, diversity, tolerance, and peace. Gontor's educational vision is manifested in two forms: (1) through the curriculum, which is demonstrated in the form of the teaching material (2) through students' daily life, in which students have to practice tolerance in a multicultural education system that is integrated into a set of rules and disciplines.

Based on the previous descriptions, PM Gontor has developed an educational system that integrated pesantren traditions and modern values. Modern values are implemented both in the learning process, the pesantren culture, cocurricular activities, and extra-curricular activities. This instrumental activity is crucial in enhancing students mental skills the spirit of work, leadership, entrepreneurship, and management. The students are all trained, and they are encouraged to be innovative and creative, which would eventually lead them to be able to survive living amidst the community. They also receive the "survival skills", such as the ability to solve problems and the ability to survive in any kind of situations. Therefore, it can be said that Pondok Gontor is a religious education institution that implements the values of modern education in an integrated manner. 


\section{References}

[1] http://www.bbc.com/indonesia/berita_indonesia/2012/10/12101 1_keluarga_bombali.shtml

[2] http://www.cnnindonesia.com/nasional/20160203201841-20108711/bnpt-19-pesantren-terindikasi-ajarkan-radikalisme

[3] Karel A. Steenbrink, Pesantren, Madrasah, dan Sekolah: Pendidikan Islam dalam Kurun Modern, (Jakarta: LP3ES, 1986).

[4] Taufik Abdullah, Islam dan Masyarakat: Pantulan Sejarah Indonesia, (Jakarta: LP3ES, 1987), h. 152

[5] M. Syafi'i Anwar, Pemikiran dan Aksi Islam Indonesia: Sebuah Kajian Politik Tentang Cendekiawan Muslim Orde Baru. (Jakarta: Paramadina, 1995).

[6] J. Casanova, Public religions in the modern world. (University of Chicago Press, 2011), h.11

[7] Ronald Lukens-Bull, Negotiating Identity and Modernity in Muslim Java (Palgrave Macmillan, 2005).

[8] Tim Penyusun, K.H. Imam Zarakasyi Di Mata Umat, (Ponorogo: Trimurti Press, 1996)

[9] Pondok Modern Darussalam Gontor, Sejarah Balai Pendidikan Pondok modern Gontor, Penggal I, h. 19

[10] Abdullah Syukri Zarkasyi, 2005. Gontor \& Pembaruan Pendidikan Pesantren. Jakarta: PT Raja Grafindo Persada.

[11] Abdullah Syukri Zarkasyi, "Sistem Pendidikan Pondok Pesantren: Pengalaman Pondok Modern Darussalam Gontor." Makalah disampaikan dalam Seminar tentang "Refleksi dan Rekonstruksi Pendidikan Islam,” diselenggarakan oleh Yayasan al-Kautsar, 31 Oktober 2002, di Jakarta Design Center.

[12] Abdullah Syukri Zarkasyi, "Mewujudkan Sekolah Islam Internasional: Sumbangan Pemikiran dari Pengalaman Pondok Modern Darussalam Gontor”. Jakarta, April 2002. 